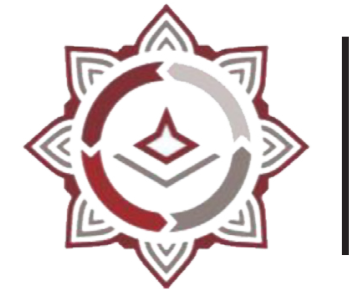

BISNIS: Jurnal Bisnis dan Manajemen Islam

P-ISSN: 2442-3718, E-ISSN: 2477-5533

Volume 9, Nomor 2, Desember 2021 (PP : 225-252)

https://journal.iainkudus.ac.id/index.php/Bisnis/index

http://dx.doi.org/10.21043/bisnis.v9i2.11914

\title{
Peran Komunitas Pengusaha Muslim Dalam Mengembangkan Bisnis Syariah di Tengah Pandemi Covid-19 (Studi kasus: Jogja Muslimah Preneur)
}

\author{
Raisa Aribatul Hamidah ${ }^{1}$, Azhar Alam ${ }^{2}$, Devi Wijayanti ${ }^{3}$, Aditya Nurrahman ${ }^{4}$ \\ Universitas Islam Batik Surakarta ${ }^{1}$ \\ Universitas Muhammadiyah Surakarta ${ }^{2,3,4}$ \\ raisaribatul9@gmail.com ${ }^{1}$,aa123@ums.ac.id²,dvwjynti04@gmail.com³, \\ adityanurrahman040@gmail.com ${ }^{4}$
}

\begin{abstract}
This study discusses the Role of the Muslim Entrepreneur Community in Developing Sharia Business in the Middle of the Covid-19 Pandemic. The purpose of this study is to reveal the role of a Sharia business community in the strategies that have been carried out by the community in developing sharia business and maintaining sharia values in muamalah during the Covid-19 Pandemic. With the research subject using eleven respondents consisting of founders, administrators and members of the Muslim entrepreneur community in the Yogyakarta region. Researchers use this type of qualitative research and the approach used is a case study method, in-depth research on individuals, groups, institutions and so on within a certain time. Collecting data by interviewing community administrators and members and collecting literature documents about maintaining sharia business in the midst of a pandemic. Based on this research, it shows that the Jogja Muslimah Preneur (JMP) community provides a role in the form of providing facilities in the form of activities and events that are useful for gaining insight, increasing competitiveness, and seeing opportunities from different perspectives. The community also plays a role in maintaining sharia values that must be maintained in doing business even in difficult circumstances such as the current Covid-19 pandemic. With all the research limitations faced, important lessons from this research can be used as a reference for other areas that want to establish a community of Muslim entrepreneurs while maintaining true Islamic values.
\end{abstract}

Keywords: Covid-19, Entrepreneur Community, Sharia Busines 


\begin{abstract}
Abstrak
Penelitian membahas peran komunitas bisnis Syariah dalam mengembangkan bisnis Syariah di Tengah Pandemi Covid-19. Tujuan dari penelitian ini adalah mengungkapkan peran sebuah komunitasi bisnis Syariah dalam strategi yang telah dilakukan komunitas dalam mengembangkan bisnis syariah dan mempertahankan nilai-nilai syariah dalam bermuamalah selama Pandemi Covid-19. Dengan subjek penelitian menggunakan sebelas responden yang terdiri dari pendiri, pengurus dan anggota komunitas pengusaha muslim di Wilayah Yogyakarta. Peneliti menggunakan jenis penelitian kualitatif dan pendekatan yang digunakan adalah metode penelitian kasus (case study), penelitian yang mendalam tentangindividu, kelompok, institusi dan sebagainya dalam waktu tertentu. Pengumpulan data dengan cara mewawancarai pengurus dan anggota komunitas serta mengumpulkan dokumen-dokumen literatur tentang mempertahankan bisnis syariah di tengah Pandemi. Berdasarkan penelitian ini menunjukkan bahwa komunitas Jogja Muslimah Preneur (JMP) memberikan peran dalam bentuk pemberian fasilitas berupa kegiatan-kegiatan dan event-event yang berguna untuk menambah wawasan, meningkatkan kemampuan daya saing, dan melihat peluang dari sudut pandang yang berbeda. Komunitas juga berperan mempertahankan nilai-nilai syariah yang harus dijaga dalam berbisnis meskipun dalam keadaan sulit seperti pandemi Covid-19 saat ini. Dengan segala keterbatasan penelitian yang dihadapi, pelajaran penting dari penelitian ini dapat digunakan sebagai referensi untuk wilayah lain yang ingin mendirikan komunitas pengusaha muslimah dengan tetap mempertahankan nilai-nilai syariah yang sebenarnya.
\end{abstract}

Kata Kunci: Covid-19, Komunitas Pengusaha, Bisnis Syariah

\title{
PENDAHULUAN
}

World Health Organisation (WHO) menyatakan coronavirus disease (Covid-19) sebagai pandemi pada 11 Maret 2020. Di Indonesia, hingga per tanggal 15 Oktober 2020 terkonfirmasi sebanyak 348.876 pasien yang positif terjangkit Covid-19. 267.851 (77,7\% dari yang terkonfirmasi) pasien yang sembuh dan 12.156 jiwa dinyatakan meninggal dunia (Satuan Tugas Penanganan Covid-19, 2020).

Dampak dari Covid-19 sendiri mengakibatkan penurunan aktivitas dari beberapa sektor, baik itu di bidang pariwisata, industri pembangunan, perdagangan sampai investasi Indonesia. Terutama pada aktivitas ekonomi yang memperkirakan resesi dan depresi. Laporan Organisation for Economic Co- operatin and Development (OECD) menunjukkan bahwa pandemi ini berdampak pada ancaman krisis ekonomi yang besar, ditandai dengan terhentinya kegiatan produksi di banyak negara, penurunan tingkat konsumsi masyarakat, hilangnya kepercayaan konsumen dan penurunan pasar saham yang menyebabkan ketidakpastian (OECD, 2020). 
Sebagai tulang punggung perekonomian nasional, usaha mikro, kecil, dan menengah (UMKM) tidak hanya sangat terpengaruh dari segi total produksi dan nilai perdagangan, tetapi juga dari segi jumlah pengangguran akibat pandemi ini. Menurut data Kementerian Koperasi dan Usaha Kecil dan Menengah (KemenkopUKM), Indonesia memiliki 64.194.057 UMKM (sekitar 99\% dari total sektor usaha) pada tahun 2018, yang mempekerjakan 116.978 .631 pekerja (sekitar 97\% dari total angkatan kerja yang bekerja di sektor ekonomi) (Pakpahan, 2020).

Banyaknya kerugian-kerugian yang dialami masyarakat karena adanya Covid-19, Entrepreneur menjadi peluang besar saat ini. Mengingat sebagian besar negara-negara maju yang makmur perekonomiannya karena memiliki banyak enterpreneur yang membuat terbukanya lapangan kerja untuk masyarakatnya. Dalam perspektif lain, seorang pakar psikologi, David Mc Clelland mengatakan bahwa salah satu syarat suatu Negara untuk mencapai tingkat kemakmuran diperlukan 7\% dari jumlah penduduknya adalah entrepreneur (Ciputra, 2009). Namun di Indonesia pada saat ini jumlah pengusahanya masih menduduki angka 3,1\%. Oleh karena itu diperlukan perubahan pergerakan dan pola pikir masyarakat akan pentingnya berwirausaha bagi masyarakat.

Ditengah pandemi ini banyak sekali cara mempelajari ber-wirausaha secara teori, seperti mengikuti pelatihan-pelatihan online atau seminar-seminar yang diadakan berbagai pihak. Salah satu seminar yang pernah diadakan adalah Bincang Online dengan judul "Peran Wanita dan Generasi Milenial dalam Kebangkitan Ekonomi" yang diadakan oleh Dinas Perindustrian dan Perdagangan Kabupaten Sleman. Di dalamnya membahas dampak-dampak Covid -19 terhadap pengusahapengusaha yang ada di daerah Sleman. Baik itu pengusaha makanan, pakaian, kerajinan tangan, dan pengusaha-pengusaha lainnya. Salah satu narasumber Dian Septiani R (sebagai Ketua Jogja Muslimah Preneur) menyampaikan selama pandemi Covid-19 mengalami penurunan tingkat konsumsi dari masyarakat maka menurunkan tingkat produksi dari produsennya.

Para pengusaha yang menjadi komunitas tersebut banyak yang merugi pada awal maret dan april, ada yang menutup produksi dan ada yang melakukan Pemutusan Hubungan Kerja (PHK) kepada karyawannya. Namun banyak pula yang melakukan peralihan bisnis. Banyaknya peralihan bisnis ini untuk menyiasati usaha masing-masing anggota. Usaha kuliner masih banyak diminati selama pandemi ini. Selain itu memproduksi Alat Perlindungan Diri (APD), membuat masker dan 
pakaian juga banyak diminati, yang intinya pengusaha akan mengikuti trend yang sedang banyak dibutuhkan masyarakat ditengah pandemi Covid-19.

Selama pandemi Covid-19 juga merebaknya masyarakat yang menjadi pengusaha kecil- kecilan, seperti menjadi reseller toko, dropshipper atau yang membuka jasa antar kirim. Namun perlu di ingat karena di Indonesia mayoritas warganya beragama Islam, sudah seharusnya masyarakat Indonesia menjalankan aktivitas sehari-harinya mempertimbangkan aspek syariah termasuk dalam berbisnis. Setiap pengusaha harus mengetahui etika bisnis seroang muslim yang sebagaimana semestinya agar setiap keuntungan yang didapatkan penuh berkah.

Berangkat dari masalah tersebut maka berdirilah beberapa komunitas pengusaha yang khusus membina pengusaha-pengusaha muslim untuk menerapkan nilai-nilai syariah dalam jiwa entrepreneurship. Entrepreneurial activity yang dijalankan komunitas pengusaha dapat meningkatkan pertumbuhan ekonomi dan layak mendapatkan perhatian pemerintah (Meutia et al., 2021). Peran komunitas pengusaha dalam mengembangan ekonomi syariah bisa dilakukan dengan mengenalkan prinsip-prinsip sistem ekonomi syariah seperti prinsip tauhid, adil, maslahat, kebebasan dan tangung jawab, persaudaraan, dan sebagainya(Takhim, 2016).

Komunitas pengusaha muslim bisa memberikan teori-teori mengenai ekonomi syariah, terkhusus bagaimanan cara berbisnis yang benar secara syariah. Disamping itu komunitas juga dapat melakukan pergerakan atau membuat kegiatan nyata yang dapat menambah wawasan anggotanya tentang berbisnis syariah. Kegiataan tersebut bisa berbentuk seminar, bazar untuk barang dagangan sesama anggota komunitas sebagai wadah sharing, atau juga melakukan kegiatan sosial. Salah satunya komunitas Jogja Muslimah Preneur (JMP). Sesuai dengan namanya komunitas ini didirikan khusus untuk para pengusaha muslimah yang ada di Jogjakarta. Didalam komunitas ini para pengusaha diajak untuk sharing ilmu bisnis dan kajian-kajian untuk menyeimbangkan urusan dunia dan akhirat. Karena dalam Islam setiap muslim wajib dan memiliki tanggung jawab dalam bekerja.

Komunitas JMP meyadari di saat era seperti ini, banyak pengusaha dan calon pengusaha yang membutuhkan ilmu pengembangan usaha yang sesuai dengan tuntutan Islam. Anggota JMP berasal dari latar belakang yang berbeda-beda, ada yang ibu rumah tangga, mahasiswa dan lainnya. Mereka bergabung karena memiliki tujuan yang sama yakni ingin meningkatkan kualitas agama, keluarga dan binisnya tetap seimbang. 
Belum banyak penelitian yang mengungkapkan peran dari sebuah komunitas pengusaha muslim dalam mengembangkan bisnis Syariah. Oleh karena itu penulis tertarik untuk meneliti bagaimana komunitas ini bekerja sesuai dengan visi dan misinya serta mengetahui perannya untuk dalam mengembangkan bisnis syariah di tengah pandemi covid-19 (studi kasus komunitas jogja muslimah preneur).

\section{KAJIAN LITERATUR}

\section{Penelitian-Penelitian Sebelumnya}

Putra (2015) yang membahas strategi UMKM dalam meningkatkan perekonomian Kota Medan dan menemukan hasil penelitiannya menunjukkan bahwa promosi paling efektif menggunakan media sosial, membuka kios untuk meningkatkan image produk dan terjun ke pasar dengan teknik menjemput bola.

Erviani (2017) menggunakan komunitas UINPreneur sebagai objek penelitiannya dan menemukan bahwa didalam komunitas tersebut melakukan kegiatan rutin mingguan berupa kelas bisnis dasar dan bisnis lanjutan. Sedangkan kegiatan bulanan seperti mengadakan workshop dan seminar wirausaha yang dilakukan di bulan-bulan tertentu.

Rahmanto etal., (2018) meneliti tentang peran komunitas dalam meningkatkan kinerja UMKM. Dikarenakan penelitian ini berfokus pada faktor internal maka ada aspek-aspek internal yang perlu diedukasikan dan diperhatikan kepada anggota komunitas seperti aspek sumber daya manusia, aspek keuangan, aspek pemasaran, aspek teknis, operasioal dan R\&D (Research dan Development).

Maulina \& Listyani (2020) membahas tentang peran perempuan anggota komunitasdalam meningkatkan perekonomiankeluarga.Disinimerekamenggunakan narasumber perempuan dengan suami tidak bekerja dan single parent. Berdasarkan temuan dataya perempuan menjalankan 3 peran yakni peran reproduktif, produktif dan kemasyarakatan. Penelitian ini menyimpulkan perempuan anggota komunitas Pahlawan Ekonomi mampu menjalankan peran tersebut dan hal tersebut membuktikan keberhasilan teori nurture dalam masyarakat. Peran produktif dapat diwujudkan dengan menjadi pengusaha maupun pekerja. Peran reproduktif juga tetap bisa dilakukan walaupun tidak sepenunya. Serta peran kemasyarakatan dapat berupa mengikuti komunitas, kegiatan keagamaan, politik dan lainnya. 
Aziza (2018) mengeksplorasi peran wirausaha Muslim dalam membangun koneksi dan komunitas. Dalam penelitiannya diketahui bahwa strategi bisnis Sari Bumi meliputi: ekspansi geografis, penyebaran bisnis, penetrasi pasar, merger dan akuisisi, rasionalitas karyawan, pengembangan bisnis, dan joint venture (bergabung dalam perusahaan patungan). Dalam membangun dunia usaha, peran kewirausahaan Sari Bumi adalah membuka lapangan kerja, membentuk kepribadian mandiri, mendorong tumbuhnya jiwa kewirausahaan, memberikan bantuan keuangan, memberi keteladanan dalam disiplin, berkomitmen untuk menjaga nilai-nilai Islam, dan berkontribusi pada kemapanan. Islam, forum tersebut membentuk forum silaturahmi, membangun landasan partisipasi dalam bidang sosial, pendidikan dan keagamaan, serta mendirikan perusahaan distribusi.

Jumlah penelitiantentangperan komunitasbisnis Syariahdalampengembangan UMKM masih sangat minim. Penelitian ini bertujuan untuk mengungkap peran yang telah dilakukan sebuah komunitas bisnis Syariah yang dibentuk oleh para pengusaha Wanita dalam mengembangkan bisnis Syariah UMKM di lingkungan mereka. Penelitian ini diharapkan menjadi rujukan dan menjadi bukti andil besar yang dapat diperankan oleh sebuah komunitas bisnis Syariah dalam pengembangan bisnisi Syariah .

\section{Komunitas Bisnis Syariah}

Komunitas, pada umumnya berdiri karena ada ikatan-ikatan dari anggotanya. DiIndonesia sendiri banyak sekali berdiri komunitas-komunitas. Komunitas tersebut tercipta dari berbagai latar belakang yang berbeda-beda, yang pada umumnya komunitas berdiri karena adanya kepentingan yang sama. Jenis-jenis komunitas yang berdiri di Indonesia banyak macamnya, seperti komunitas.Legalitas suatu komunitas di Indonesia diatur dalam Undang-Undang Republik Indonesia Nomor 17 tahun 2013 tentang Organisasi Kemasayarakatan. Pasal 1 (satu) berbunyi

"Organisasi Kemasyarakatan yang selanjutnya disebut Ormas adalah organisasi yang didirikan dan dibentuk oleh masyarakat secara sukarela berdasarkan kesamaan aspirasi, kehendak, kebutuhan, kepentingan, kegiatan, dan tujuan untuk berpartisipasi dalam pembangunan demi tercapainya tujuan Negara Kesatuan Republik Indonesia yang berdasarkan Pancasila(Undang-Undang Republik Indonesia Nomor 17 Tahun 2013) 
Di era sekarang komunitas bisnis banyak menjamur, contohnya Komunitas Pengusaha Muslim Indonesia (KPMI), Komunitas Enterpreneur Muda Indonesia, IIBF ( Indonesia Islamic Business Forum), Komunitas Bisnis Online, Tangan di atas Community dan masih banyak komunitas lainnya. Namun tidak semua komunitas melegalkan komunitas, hal ini dikarenakan banyaknya komunitas yang sengaja menjadikan perkumpulannya itu sebagai ajang tukar pikiran

Kewirausahaan (Entrepreneurship) adalah salah satu jenis kreativitas dan kemampuan berinovasi yang digunakan sebagai dasar, keterampilan dan sumber daya untuk menemukan peluang sukses. Kewirausahaan adalah kemampuan seseorang untuk menciptakan hal-hal baru melalui pemikiran kreatif dan peluang inovatif untuk menciptakan peluang (Daryanto, 2018). Kewirausahaan merupakan proses penciptaan sesuatu yang berbeda nilainya dengan menggunakan usaha dan waktu ynag diperluan, memikul resiko finansial, psikologi dan sosial yang menyertainya, serta menerima balas jasa moneter dan kepuasan pribadi (Hastuti, 2020).

Syariah merupakan ketetapan-ketetapan Allah dan ketentuan Rasul-Nya, baik berupa larangan maupun anjuran meliputi seluruh aspek hidup dan kehidupan manusia (Ali, 2011). Jika dilihat dari segi ilmu hukum, syariat merupakan norma hukum dasar yang ditetapkan Allah, yang wajib diikuti oleh orang Islam berdasarkan iman yang berkaitan dengan akhlak, baik dalam hubungnnya dengan Allah maupun dengan sesama manusia dan benda dalam masyarakat.Dengan begitu semua aspek di dunia ini sudah diatur dalam syariat. Syariat mencakup ibadah mahdhah dan ghairu maghdah(Nurhayati, 2018).

Dari penjelasan-penjelasan diatas dapat ditarik kesimpulan bahwa yang dimaksud dengan entrepreneur syariah adalah segala aktivitas bisnis yang diusahakan dengan mencari peluang, inovatif dan kreatif dalam bentuk memproduksi suatu barang atau jasa yang dalam menjalankannya berdasarkan syariat Islam.

\section{Dasar Hukum dan Etika Entrepreneurship Syariah}

Praktik wirausaha syariah banyak diatur dalam Al-Qur'an, rekomendasi ataupun larangan yang dilakukan dalam bisnis Syariah (Ariyadi, 2018). salah satu ayatnya adalah QS. Al-Baqarah ayat 275 : “.Padahal Allah telah menghalalkan jual beli dan mengharamkan riba.... ". Dalam hadist nabi secara jelas diterangkan tentang praktek bisnis secara praktis dan teoritis secara Syariah (Masruri, 2014). Hadis Nabi yang diriwayatkan oleh Al Bukhari : Artinya: "Penjual dan pembeli boleh melakukan 
khiyar selama mereka berdua belum berpisah. Apabila mereka berdua benar dan jelas, maka mereka berdua diberi keberkahan didalam jual beli mereka, dan apabila mereka berdua berbohong dan merahasiakan, maka dihapuslah keberkahan jual beli mereka berdua. ( HR. Al - Bukhari).(Masruri, 2014)

Dalam bisnis syariah, akad menjadi sesuatu yang penting. Secara khusus, Akad mengungkapkan hubungan antara ijab (pernyataan penawar / pengalihan kepemilikan) dan qabul (representasi penerima kepemilikan), yang akan dijelaskan dalam ruang lingkup yang diisyaratkan (Ariyadi, 2018).

Menurut Qardhawi dalam Usniah \& Alhifni (2017) bisnis dan moralitas (etika) saling berkaitan karena moralitas sangat penting dalam kehidupan Islam. Karena tanpa memperhatikan akhlak dalam berbisnis para pengusaha akan menghalalkan segala cara baik itu halal maupun haram. Secara umum Prinsip-prinsip etika bisnis Islam dapat dilihat dari penyatuan ASIFAT, yaitu: Akidah (ketaatan kepada Allah SWT), Shiddiq (benar), Fathanah (kecerdasan), Amanah (jujur / amanah) dan Tabligh (komunikasi yang baik), dan juga tidak melakukan hal-hal yang bertentangan dengan hukum Islam.

\section{Perilaku dan Pengembangan Entrepreneurship Syariah}

Perilaku seorang muslim sangat diperlukan dalam berbisnis hal ini sebagai investasi yang dapat menguntungkan dan menjamin kehidupannya di dunia dan seterusnya. Untuk melihat perilaku bisnis seorang muslim bisa melalui ketakwannya, kebaikannya, sikap amanahnya, cara mereka memberikan pelayanan pembeli dengan ramah, dan semua aktivitas bisnisnya yang dijalankan hanya untuk ibadah(Agustin, 2017). Islam telah mengatur cara mengembangkan bisnis syariah diantaranya: niat yang baik, berinteraksi dengan akhlak, percaya pada takdir dan ridha, bersyukur, menganggap kerja sebagai ibadah, menjaga aturan syariah, bersikap rendah hati dan menghindari kesombongan serta menerapkan disiplin waktu (Chilyatunnisa', 2016).

Pengembangan Enterpreneruship Syariah dapat dilakukan melalui berbagai cara. Pertama, melalui perluasan skala ekonomi dengan meningkatkan skala produksi, tenaga kerja, teknologi, sistem distribusi, dan tempat usaha. Kedua, melakukan perluasan cakupan usaha dengan menambah jenis usahabaru, produkdan jasa baru, yang berbeda dari yang diproduksi sekarang (diversifikasi) dan teknologi yang berbeda. Ketiga memelihara spirit usaha melalui mendidik wirausaha tentang pelayanan perusahaan ( alasan mereka memberi produk dan jasa, masalah yang 
dihadapi pelanggan, tentang kebutuhan dan keingin dari pelanggan secara spesifik, mendidik wirausaha tentang nilai- nilai perbaikan produk dan pemasarannya, proses distribusi dan kemampuan bersaing, menciptakan iklim kerja yang positif yang mendorong terciptanya ide-ide baru(Basrowi, 2011).

\section{Kondisi UMKM di tengah Pandemi Covid-19.}

Sejak virus Covid-19 melanda dan menyebar di Indonesia, dengan cepat perekonomian di Indonesia langsung terkena dampaknya. Seperti bursa saham yang terjun bebas, harga minyak bumi yang jatuh, dan komoditas lain seperti gas dan minyak sawit. Pariwisata menjadi salah satu sektor yang terkena dampaknya. Penurunan pariwisata sendiri mengakibatkan penurunan produktivitas pada UMKM. Ketua Umum Asosiasi UMKM Indonesia (Akumindo), Ikhsan Ingrabatun memperkirakan omset UMKM di Sektor non kuliner turun 30-35\% sejak Covid-19. Penjualan tatap muka atau pertemuan antara penjual dan pembeli menjadi penyebab utamanya(Amri, 2020).

Adanya imbauan untuk social distancing dan physical distancing menyebabkan masyarakat lebih memilih untuk melakukan kegiatan diluar rumah salah satunya untuk berbelanja. Beberapa kemudahan yang ditawarkan dalam berbelanja online menjadikan para pengusaha dalam UMKM untuk menguasai teknik dalam berbelanja lewat digital untuk tetap memberikan pelayanan kepada konsumen (Amri, 2020). Beberapa alasan yang menyebabkan masyarakat lebih memilih untuk berbelanja online yaitu pertama, meminimalkan biaya. Dengan berbelanja konsumen tidak perlu membayar biaya akomodosi untuk mencapai pasar/toko. Ditambah lagi sekarang banyak pada penjual atau toko yang mengadakan diskon, promo atau cara-cara lainnya untuk menarik konsumen. Kedua, mengurangi aktifitas fisik di luar rumah. Ketiga, efisiensi waktu. Di zaman sekarang efisiensi waktu sangat di prioritaskan, dengan berbelanja online para konsumen akan tetap bisa berbelanja dan juga mengerjakan aktifitas lainnya(Amri, 2020).

Dimasa pandemi sekarang, mempertahankan produk dan mempertahankan pelanggan yang sudah ada menjadi hal urgensi lainnya. Karena kepuasan pelanggan menciptakan loyalitas pelanggan. Salah satu cara yang bisa dilakukan UMKM adalah melakukan pemasaran hubungan pelanggan.

Konsep pemasaran tersebut dilkukan dengan emelihara hubungan yang kokoh dan saling menguntungkan antara penyedia jasa dan pelanggan, sehhingga 
dapat terjalin transaksi berulang dan menciptakan loyalitas pelanggan. Menurut penelitian Farida et al., (2017) pemasaran dengan memelihara hubungan pelanggan berpengaruh positif dan signifikan terhadap peningkatan kinerja pemasaran UMKM. Semakin baik kualitas hubungan pelaku UMKM dengan konsumen, pemasok dan yang ainnya, semakin baik pula kemampuan untuk meningkatkan kinerjapemasarannya (Hardilawati, 2020).

\section{METODE PENELITIAN}

Penelitian ini menggunakan pendekatan penelitian kasus (case study). Studi kasus merupakan jenis penelitian kualitatif yang mendalam tentang individu, kelompok, institusi dan sebagainya dalam waktu tertentu(Sugiarto, 2015). Pemilihan subjek dalam penelitian atau para responden ini menggunakan metode purposive, yaitu melalui pemilihan informan yang dirasa memiliki hubungan dengan tujuan penelitian dan dianggap cukup mengetahui tentang permasalahan penelitian (Neuman, 2013). Para responden yang dipilih terdiri dari founder, pengurus komite dan anggota Jogja Muslimah Preneur Community. Founder, pengurus komite dan anggota komunitas. Pemilihan ini berdasarkan kesesuaian dengan judul peneliti yang ingin menganalisis peran komunitas dalam mengembangkan bisnis syariah.

Penelitian ini menampilkan hasil analisa strategi yang dilakukannya berdasarkan dua sudut pandang, dari tujuan komunitas yang menjadi acuan para founder, pengurus dan dampak yang dirasakan para anggota komunitas. Penelitian ini melakukan wawancara melalui WhatsApp menggunakan fitur voicenote, hal ini dikarenakan kebijakan PSBB (Pembatasan Sosial Berskala Besar) di wilayah Jateng - DIY terus diberlakukan.

Anggota JMP terdiri dari pengusaha yang menjalankan bisnis di berbagai bidang. Selama pandemi Covid-19 semua pengusaha merasakan dampak dari wabah tersebut. Anggota komunitas JMP banyak yang melakukan peralihan bisnis untuk mempertahankan usahanya. Jenis usaha dalam JMP Community diklasifikasikan menjadi beberapa macam, seperti bisnis fashion dan hijab, makanan, asesoris rumah, kebutuhan APD (Alat perlindungan diri) selama Covid-19, dan bisnis dalam bentuk penawaran jasa. Dari banyaknya anggota Jogja Muslimah Preneur, peneliti mengambil lim anggota JMP Community.

Responden ini diambil dengan mempertimbangkan klasifikasi usaha yang sedang dijalankan. Dua responden dari founder JMP diambil untuk mengetahui 
kinerja dan perkembangan dari komunitas. Peneliti juga mewawancarai pengurus komite komunitas untuk mengetahui kegiatan-kegiatan secara merinci dan dampak yang diinginkan dari kegiatan yang sudak dilaksanakan. Responden anggota diambil berdasarkan klasifikasi usaha yang dibentuk komunitas JMP, peneliti ingin mengetahui dampak dari kegiatan yang diadakan komunitas dari sudut pandang anggota sebagai pemilik masing-masing jenis usaha. Berikut daftar responden Komunitas Jogja Muslimah Preneur :

Tabel 2 Data responden dari founder dan Pengurus Komite Komunitas Jogja Muslimah Preneur (JMP)

\begin{tabular}{|c|c|c|}
\hline No & Nama & Jabatan \\
\hline 1. & Iffah M Dewi & $\begin{array}{l}\text { Founder JMP } \\
\text { Owner:@Soganbatik }\end{array}$ \\
\hline 2. & Dian Septiani rahayu & $\begin{array}{l}\text { Founder dan President JMP } \\
\text { Owner:@disera.agency }\end{array}$ \\
\hline 3. & Zunaizah Qudwatunnisa & $\begin{array}{l}\text { Divisi Social and Charity } \\
\text { Owner: Ayyahijab } \\
\text { (@ayyahijab.official dan } \\
\text { @ayyahijab.kids }\end{array}$ \\
\hline 4. & Fitria Kusuma & $\begin{array}{l}\text { Divisi Informasi dan Teknologi } \\
\text { Owner :@desainkewae dan } \\
\text { @Happyboxandco }\end{array}$ \\
\hline 5. & Anisa Kusuma Wijayanti & $\begin{array}{l}\text { Divisi Public Relation } \\
\text { Owner :@misslunaly dan } \\
\text { @luneco.id }\end{array}$ \\
\hline 6. & Sholihah Wardawati & $\begin{array}{l}\text { Divisi Community } \\
\text { Development } \\
\text { Owner:@cv.bima_aksara_nusa }\end{array}$ \\
\hline
\end{tabular}

Tabel dua berisi nama-nama responden yang menjadi sumber utama informasi dalam penelitian penulis. Melalui responden diatas, data yang dibutuhkan penulis sudah cukup. Namun karena tujuan peneliti ingin menganalisis strategi 
yang digunakan komunitas maka peneliti memerlukan data yang diperoleh dari anggota komunitas sebagai informasi tambahan dan memberikan sudut pandang yang berbeda.

Tabel 3 Data responden dari anggota Komunitas Jogja Muslimah Preneur

\begin{tabular}{|c|c|c|c|}
\hline No & Nama & Jenis Usaha & $\begin{array}{c}\text { Nama Usaha (akun } \\
\text { Instagram) }\end{array}$ \\
\hline 1. & Aulia Hijriastuti & Fashion & $\begin{array}{l}\text { @Alula } \\
\text { dan batik) }\end{array}$ \\
\hline 2. & $\begin{array}{l}\text { Laila } \\
\text { Paramita }\end{array}$ & Souvenir & @lellalells \\
\hline 3. & $\begin{array}{ll}\text { Nurul } & \text { Santika } \\
\text { Agnha Maredy } & \end{array}$ & Kuliner & $\begin{array}{l}\text { @Zidan.Zahira. } \\
\text { Cathering }\end{array}$ \\
\hline 4. & Vanny Mediana & $\begin{array}{l}\text { Kuliner dan } \\
\text { Jasa }\end{array}$ & $\begin{array}{l}\text { @sekargendhis_Jogja } \\
\text { @kioskami.jogja } \\
\text { @kromatography.id }\end{array}$ \\
\hline 5. & Wini Devina & $\begin{array}{l}\text { Fashion dan } \\
\text { Kuliner }\end{array}$ & $\begin{array}{l}\text { @longsleevehijab } \\
\text { @warungtetehque } \\
\text { (Mantan divisi Islamic } \\
\text { Studies dan President } \\
\text { Jogja Muslimah } \\
\text { Preneur) }\end{array}$ \\
\hline
\end{tabular}

Tabel tiga berisi nama-nama responden dari anggota komunitas Jogja Muslimah Preneur. Pemilihan responden tersebut berdasarkan pertimbangan yang mendalam ketika menentukan responden tersebut, karena anggota komunitas JMP terdiri dari berbagai jenis pengusaha. Maka penelitian ini memutuskan mengambil narasumber lima pengusaha dengan jenis usaha yang berbeda-beda agar memberikan pendapat yang lebih obyektif. 


\section{PEMBAHASAN}

\section{Peran Komunitas dalam Mengembangkan Bisnis Syariah di Tengah Pandemi Covid-19}

Komunitas pengusaha memiliki peran penting bagi para pengusaha baru yang membutuhkan bimbingan atau perkumpulan untuk mengembangkan kemampuan serta koneksi bisnisnya. Dengan adanya Pandemi Covid-19 membuat para pengusaha di Indonesia terkena imbasnya, termasuk pengusaha UMKM. Sektor UMKM yang terguncang selama pandemi Covid-19 yakni makanan dan minuman serta industri kreatif dan pertanian. Penurunan jumlah produksi dalam usaha UMKM membuat para pengusahanya melakukan berbagai cara untuk mempertahankan bisnis masing-masing. Komunitas Jogja Muslimah Preneur (JMP) dengan jumlah anggota komunitas sebanyak 467 orang menjadi salah satu contoh komunitas dengan anggota para pengusaha muslim yang berjuang untuk mempertahankan usahanya di tengah Pandemi Covid-19. Salah satu peran yang diberikan komunitas Jogja Muslimah Preneur (JMP) mengadakan kelas-kelas bisnis yang isinya memberikan materi cara mempertahankan bisnis di tengah Pandemi Covid-19 dengan memanfaatkan platform yang sedang banyak digunakan oleh masyarakat.

Selain itu, komunitas Jogja Muslimah Preneur juga memberikan beberapa perannya kepada anggota komunitas, secara ringkasnya peran tersebut tergambar dalam tabel berikut

Tabel 3

Peran Komuniats JMP Kepada Anggota

\begin{tabular}{ll}
\hline \multicolumn{1}{c}{ Klasifikasi Peran } & \multicolumn{1}{c}{ Bentuk Kerjasaa } \\
\hline $\begin{array}{l}\text { Membangun Kerja Sama (Relasi } \\
\text { Bisnis) }\end{array}$ & $\begin{array}{l}\text { Bekerjasama dengan Dinas Perindustrian dan } \\
\text { Perdagangan }\end{array}$ \\
\cline { 2 - 2 } & Mempromosikan Usaha anggota komunitas \\
\hline \multirow{3}{*}{$\begin{array}{l}\text { Membangun Sinergi dalam } \\
\text { Komunitas }\end{array}$} & $\begin{array}{l}\text { Mengadakan kerjasama antar anggota dengan } \\
\text { Development Class (CDC), Event Organizer (EO), } \\
\end{array}$ \\
\cline { 2 - 2 } & Public Relation (PR) dan Islamic Studies (IS) \\
\hline & Menguatkan dan melatih Jiwa Enterpreneur \\
\hline
\end{tabular}




\section{a. Membangun Kerja Sama (Relasi Bisnis)}

Sharing menjadi salah satu tujuan seseorang ikut bergabung dengan komunitas. Komunitas Jogja Muslimah Preneur (JMP) bertujuan membangun kerja sama baik antar anggota sebagai pihak internal maupun dengan partner JMP sebagai pihak eksternal. Sejak Pandemi Covid-19, mempertahankan usaha menjadi fokus utama para anggota komunitas JMP. Dengan tradisi "nglarisi konco dewe" sesama anggota membantu mempromosikan dan membeli produk atau jasa hasil anggota lainnya. Kegiatan ini sangat membantu para anggota untuk tetap percaya diri dalam mempertahankan usahanya. Salah satu bentuk peran komunitas JMP kepada anggotanya, merekap usaha beberapa anggota yang bersedia di promosikan melalui poster lalu poster tersebut disebar di grup whatsapp seluruh anggota dan meng-upload pada sosial media partner JMP yang memiliki followers banyak sehingga memperluas jangkauan pasar konsumennya.

\section{Gambar 1 Promosi yang dilakukan Komunitas JMP}

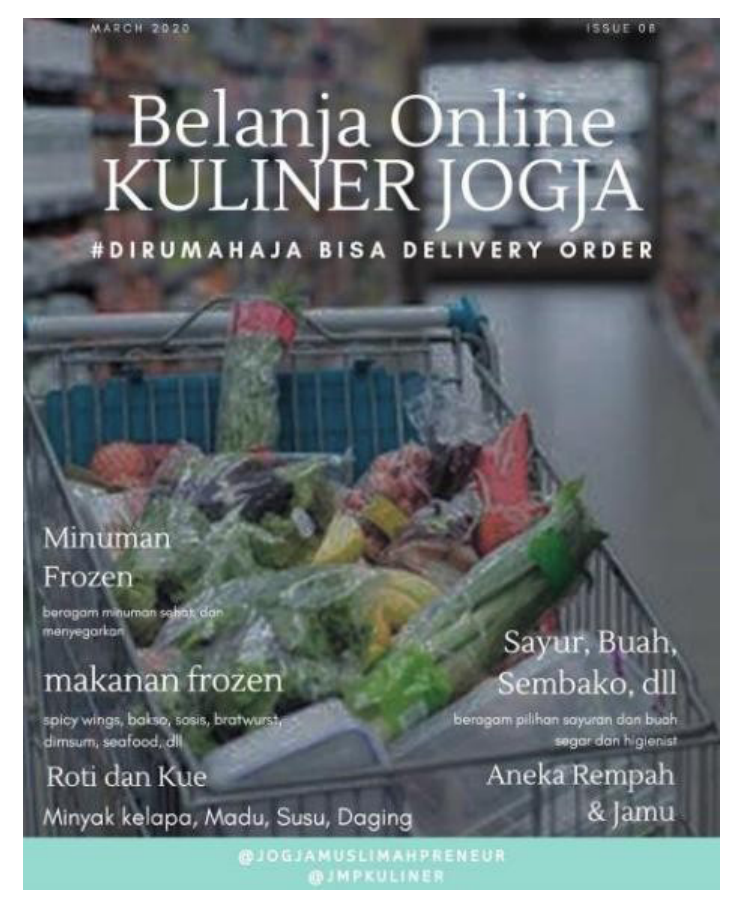

Sumber: Instagram Komunitas JMP 2020

Untuk mengenalkan komunitas JMP kepada masyarakat luas JMP juga melakukan kerja sama dengan beberapa partner salah satunya kerja sama 
dengan DISPERINDAG (Dinas Perindustrian dan Perdagangan) Provinsi Daerah Istimewa Yogyakarta. Tujuan kerja sama ini adalah untuk memberikan ruang dan kesempatan kepada member JMP dalam mempromosikan usahanya melalui pameran-pameran.

\section{b. Membangun Sinergi dalam Komunitas}

\section{Menciptakan kerja sama anggota}

Para anggota JMP (Jogja Muslimah Preneur) terus menjaga tali persaudaraan sesama anggotanya tidak menganggap anggota lainnya sebagai musuh dalam berjualan. Selama Pandemi Covid-19 melanda Indonesia, penjualan para anggota komunitas menurun. Penurunan omset penjualan menjadikan para entrepreneur menyusun strategi penjualan agar mengembalikan omset seperti semula. Salah satu upaya yang dilakukan adalah mengalihkan penjualan dari toko offline menjadi penjualan online.

Dengan perkembangan e-commerce yang begitu cepat, akan mempermudah para anggota komunitas (para entrepreneur) untukmeneruskan usahanya dan menciptakan ide-ide baru. (Efana Rahwanto, 2020)

\section{Mengadakan berbagai kegiatan}

Secara garis besar kegiatan komunitas Jogja Muslimah Preneur (JMP) dibagi menjadi :

\section{a) Community Development Class (CDC)}

Komunitas Jogja Muslimah Preneur (JMP) memberikan kelas setiap bulannya dengan tema mengikuti kebutuhan ilmu dari member JMP dan melihat perkembangan bisnis. Sejak Pandemi Covid-19 melanda perekonomian UMKM, materi yang disampaikan lebih terfokuskan pada strategi pengusaha dalam mempertahankan bisnisnya di tengah Pandemi.

Berikut adalah kegiatan Community Development Class yang sudah terlaksana pada periode 2020 : 
Tabel 4

Agenda Community Development Class (CDC)

\begin{tabular}{lll}
\hline Waktu Pelaksanaan & Nama kelas Bisnis & Bentuk \\
\hline 14 Januari 2020 & $\begin{array}{l}\text { Business Trip (kelas bisnis) goes to Dowo, } \\
\text { Jejamuran dan Desa Wisata Pentingsari }\end{array}$ & Offline \\
\hline 28 Februari 2020 & Optimasi Konten Instagram & Online \\
\hline 3 April 2020 & How to keep Calm and Carry On \#Covid 19 & Online \\
\hline 24 Juni 2020 & Yuk Belajar Etika Bisnis & Online \\
\hline 29 Juli 2020 & Memutar Ide Anti Mati Gaya & Online \\
\hline 12-13 September 2020 & Smartphone Videography Class & Online \\
\hline November 2020 & Optimalisasi Tiktok for Bisnis & Online \\
\hline
\end{tabular}

Sumber: data diolah 2021

Kegiatan kelas bisnis ini sangat bermanfaat untuk setiap anggota komunitas dalam mengembangkan jiwa wirausahanya, "JMP gudang ilmu bagi saya, karena setelah bergabung dengan JMP saya jadi tahu yang namanya Digital Marketing, Branding, ilmu Online shop" ungkapan Ibu Ayun Zunaizah.

\section{b) Social and Charity (SC)}

Kegiatan Social and Charity selama pandemi dilakukan secara online. Pada bulan Maret- April 2020 komunitas JMP mengadakan penggalangan dana dengan jumlah hampir tiga puluh juta rupiah, dana tersebut disalurkan untuk tenaga medis di Yogyakarta yang menangani Covid-19. Komunitas JMP juga memiliki kegiatan sosial rutin "Sedekah Jum'at". Kegiatan ini bekerja sama dengan yayasan yang bernama Gerakan Infaq Beras, komunitas bertugas mengumpulkan beras untuk diberikan ke Pondok Pesantren yang ada di Jogja. Donasi dikumpulkan setiap hari Jum'at lalu komunitas menyetorkan hasil donasi kepada yayasan setiap sebulan sekali. 
Gambar 2 Poster kegiatan social and charity komunitas JMP 2020

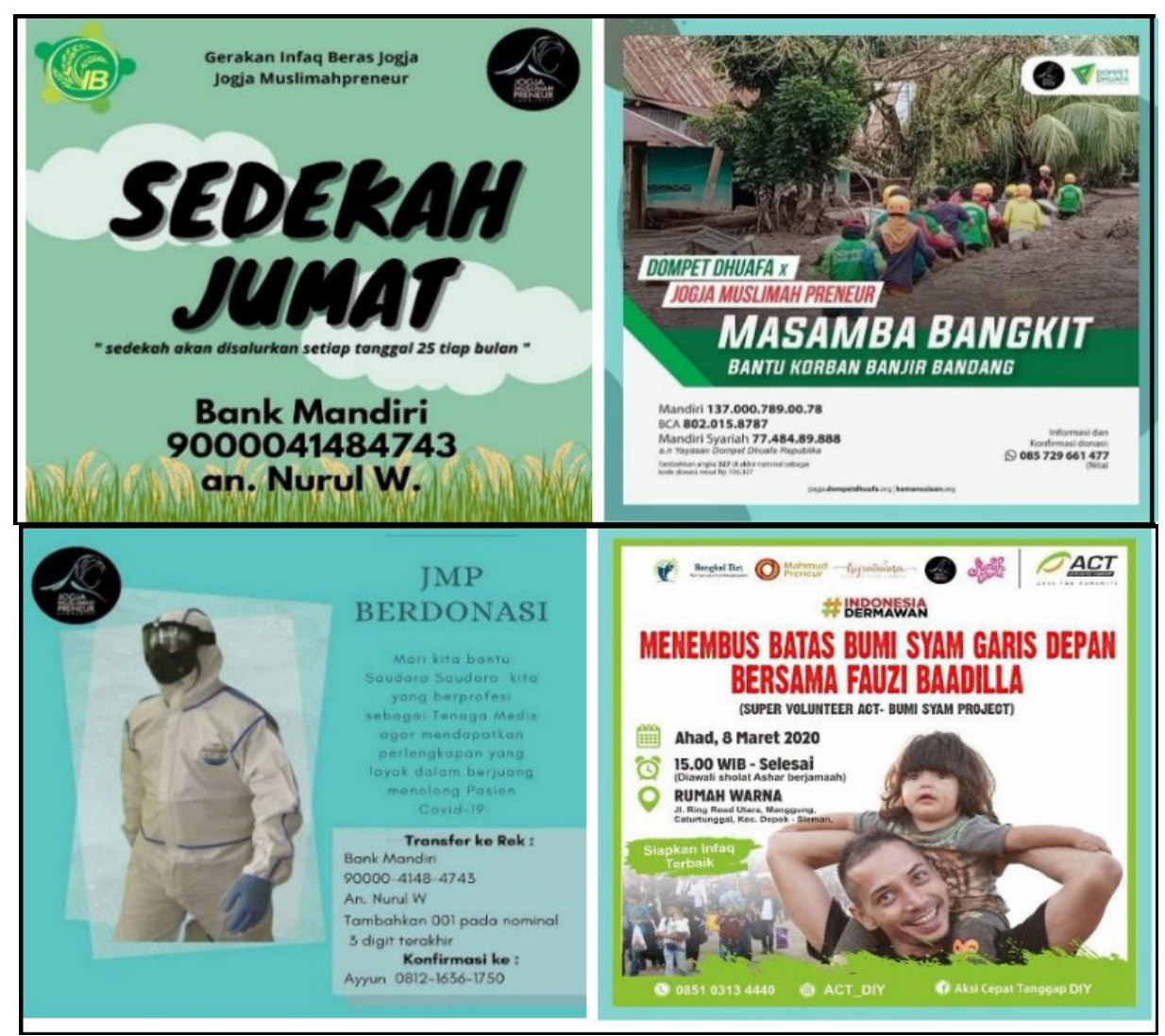

Sumber: Instagram Komunitas JMP

Komunitas JMP juga melakukan kerja sama dengan ACT (Aksi Cepat Tanggap) dompet dhuafa, pelatihan mitigasi bencana gempa, buka bersama saat ramadhan dengan anak panti asuhan, program orang tua asuh untuk anak-anak yang kurang mampu. Namun kegiatan tersebut terkendala pada pendistribusian.

\section{c) Event Organizer (EO)}

Event Organizer adalah kegiatan-kegiatan yang diadakan komunitas JMP berskala besar dengan tema-tema yang dibutuhkan member JMP seperti seminar, bazar dan talkshow. Kegiatan ini menghadirkan seorang influencer dan tokoh-tokoh yang menginsipirasi. Komunitas Jogja Muslimah Preneur (JMP) membuat event lain seperti kunjungan ke beberapa industri fashion, kuliner maupun craft sebagai referensi maupun usaha inovasi ide dan menambah wawasan baru bagi para pejuang bisnis member JMP. 
Berikut beberapa event yang sudah dilaksanakan pada tahun 2020 :

Tabel 5

Agenda Event Organizer 2020

\begin{tabular}{|c|c|c|c|}
\hline Tanggal Acara & Bentuk Acara & Tema Acara & Pembicara \\
\hline 5 April 2020 & $\begin{array}{l}\text { Webinar } \\
\text { Online }\end{array}$ & $\begin{array}{l}\text { Antisipasi Bisnis di Tengah } \\
\text { Krisis saat Ramadhan }\end{array}$ & $\begin{array}{l}\text { Farid Fatahilah dan } \\
\text { Hutami Nadya }\end{array}$ \\
\hline 23 April 2020 & $\begin{array}{l}\text { Instagram } \\
\text { Live Talkshow }\end{array}$ & Keep Iman, Keep Imun & $\begin{array}{l}\text { Dr. Arif Sabta Aji, S.Gz } \\
\text { dan Galuh Irawati K, } \\
\text { S.Psi }\end{array}$ \\
\hline 7 Mei 2020 & Webinar & $\begin{array}{l}\text { Strategi Jitu Dongkrak } \\
\text { Penjualan Usaha Lewat } \\
\text { Food Delivery }\end{array}$ & $\begin{array}{l}\text { Agus Yahya Sukmana } \\
\text { (Owner Sate Taichan } \\
\text { Bengawan) dan Heru } \\
\text { Prianka (Owner Satu } \\
\text { Pintu Coffe) }\end{array}$ \\
\hline Juni 2020 & Webinar & Kebangkitan UMKM & $\begin{array}{l}\text { Iffah M. Dewi (Owner } \\
\text { Sogan Batik) }\end{array}$ \\
\hline
\end{tabular}

Sumber: data diolah 2021

\section{d) Public Relation (PR)}

Public Relation adalah divisi yang memiliki peran menyediakan fasilitas dan kemudahan antar anggota komunitas dan membantu mempererat tali silaturahmi antar anggora sehingga terjadi hubungan yaang bersinergi. Fungsi dari adanya kegiatan public relation untuk memperkenalkan komunitas kepada public dan menarik partner JMP (badan- badan, perusahaan atau mitra) untuk bekerja sama dengan komunitas JMP. Komunitas JMP memiliki merchant diluar anggota JMP diantaranya Jogja Traditional Treatment, Panties Pizza, Wardah dan Safi.

\section{e) Islamic Studies (IS)}

Islamic Studies adalah kegiatan rutin yang dilakukan berupa pengajian khusus putri dengan mengambil tema besar kemuslimahan, akhlak, fiqh, muamalah (perniagaan), aqidah atau sirah, manajemen keluarga sakinah dan ibadah. Kegiatan kajian dalam JMP dibuat secara bereguler dan bersilabus agar kajian ini sesuai target. 
Berikut silabus Ngaji Bisnis yang diajarkan untuk komunitas : 1 . Mengapa Muamalah harus sesuai syariah dan urgenai fiqih muamalah, 2. Konsep harta dan kepemilikan dan konsep akad dalam muamalah, 3. Kaidah bisnis dalam islam, 4. Jual beli sesuai syariah, 5. Persyartan jual beli tempo (Kredit), 6. Sewa (Ijarah) dan Kepegawaian (Ijarotul Ajiir), 7. Utang, pinjaman dan riba, 8. E-Money, 9. Syirkah, 10. Model Dropshipper yang diperbolehkan, 11. Agunan/Jaminan, 12. Permakelaran, 13. Perwakilan, 14. Titipan dan pinjam meminjam, 15. Pemberian hadiah bersyarat.

\section{Menguatkan dan Melatih Jiwa Enterpreneur}

Dengan adanya Pandemi Covid-19 banyak anggota komunitas pesimis dengan bisnis yang dijalankan. Dengan bergabung dalam komunitas JMP sesama anggota akan melakukan upaya untuk menumbuhkan dan menguatkan jiwa entrepreneur pada member JMP. Melalui kelas-kelas yang diadakan selama pandemi, para anggotanya dituntut untuk mendapatkan tiga hal, diantaranya : dapat melihat peluang, berfikir kreatif dan inovatif dan mampu menghadapi segala risiko.Memperhatikan lingkungan dan kondisi terkini akan membuka pikiran seorang pebisnis akan peluang baru. Di tengah Pandemi Covid-19 persaingan antar usaha bukan menjadi jalan utama dan satu-satunya. Berkolaborasi dan bekerja sama bisa menjadi peluang agar usaha tetap berjalan. Banyak cara yang digunakan para pebisnis dalam mempertahankan usahanya di tengah pandemi diantaranya penyesuaian sistem produksi dan marketing produknya. Seperti upaya yang dilakukan oleh anggota komunitas pemilik Ayyahijab, memproduksi bergo daily dengan jumlah yang besar dan promosi yang diup kan secara prioritas. Strategi yang lain bisa melalui peralihan usaha ke masker, menekan biaya produksi dan marketing, fokus ke salah satu produk yang digemari masyarakat. Membuat banyak promo seperti memberikan diskon, tidak menyediakan sistem ready namun beralih dengan sistem PO (Pre-Order), reshoot membuat foto katalog baru untuk produk lama agar menggiring perspektif konsumen.

\section{Strategi yang Dilakukan Komunitas untuk Mempertahankan Nilai Nilai Syariah dalam Bermuamalah}

Tujuan penerapan syariah dalam bermuamalah pada hakikatnya agar tercipta pendapatan yang berkah dan mulia dan Menjauhkan sumber daya alam dari usaha eksploitasi. Komunitas Jogja Muslimah Preneur (JMP) juga mempertahankan nilai- 
nilai syariah dalam bermuamalah tersebut dan mempertahankan kaidah seorang muslimah yang menjalankan tugas sebagai ibu rumah tangga, pelajar dan sebagai seorang pengusaha.

Membekali ilmu pengetahuan mengenai syariah kepada anggotanya menjadi strategi utama yang diberikan komunitas JMP. Banyak kelas yang diadakan oleh komunitas JMP salah satunya kelas Kajian Keputrian adalah kajian yang diadakan dua minggu sekali,dengan materi seperti akad-akad dalam bermuamalah, jualah dan mempelajari bisnis secara kontemporer. Kajian "Strategi Marketing Langit" menjadi salah satu materi kajian yang sangat berguna untuk anggota JMP. Melalui "Strategi Marketing Langit" mengajarkan anggota JMP dalam bermuamalah agar tetap mengingat agamanya diatas strategi-strategi marketing duniawi.

Berikut beberapa kajian yang sudah dilakukan pada Pandemi Covid-19 tahun 2020 :

Gambar 3 Agenda Kajian Keputrian 2020

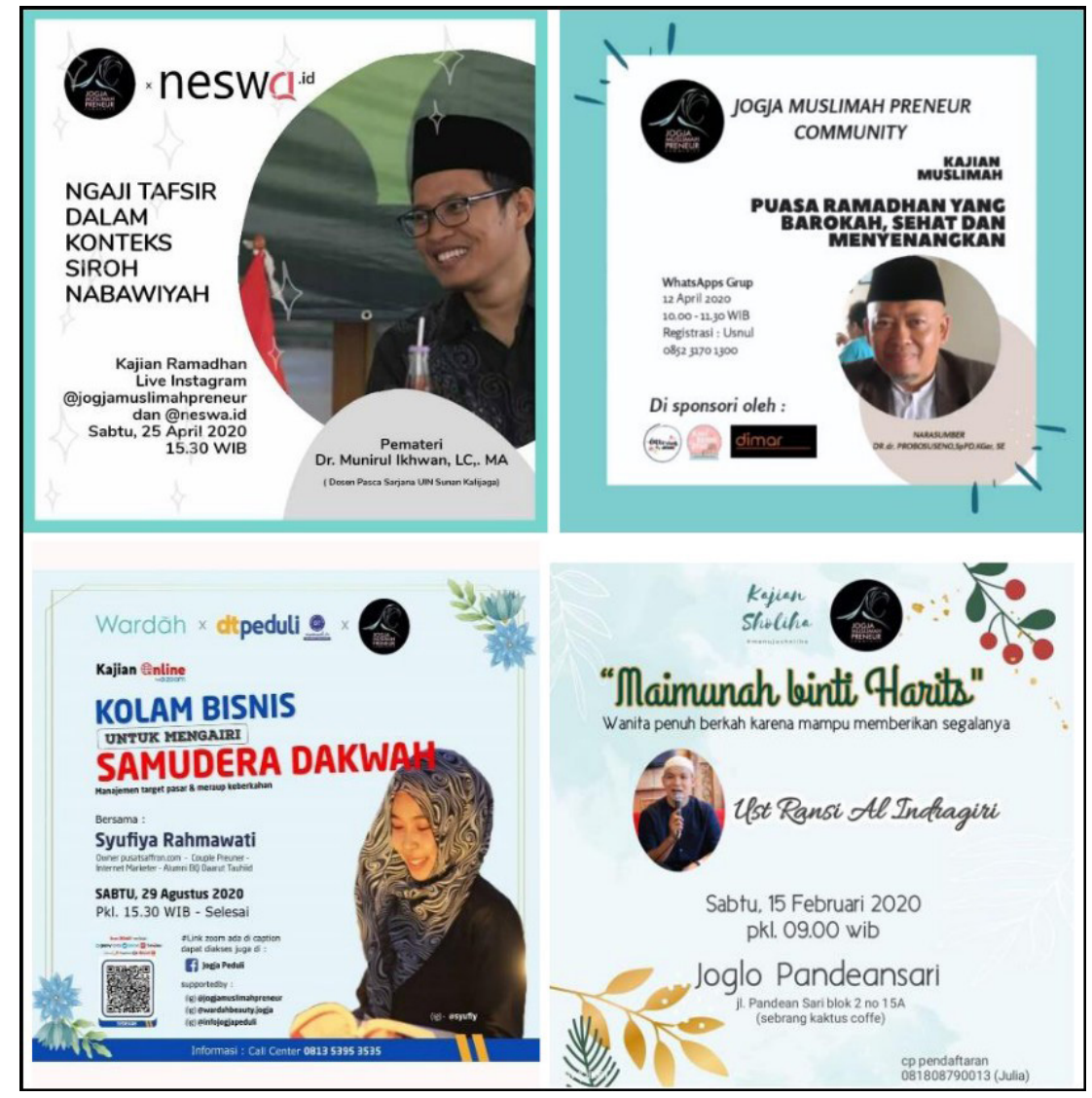

Sumber: Instagram Komunitas 
Kajian ini diadakan untuk anggota JMP dan umum."Kajian ini terdapat kendala banyaknya aliran-aliran dan pandangan fiqih yang berbeda-beda, sehingga kegiatan ini dilakukan diluar divisi" ungkap Wini Devina. Menerapkan Nilai Syariah ketika Bermuamalah dalam menjalankan Bisnis. Dalam komunitas, mewujudkan visi misi menjadi tugas bersama antara pendiri komunitas dengan anggota komunitas. Tugas pendiri komunitas dan para komitenya memberikan bekal ilmu melalui kelaskelas bisnis dan kajian kajian yang dilakukan. Selanjutnya para anggota komunitas merealisasikan ilmu tersebut dalam menjalankan bisnisnya.

\section{Pembahasan Peran dan Strategi Komunitas dalam Mengembangkan dan Mempertahankan Bisnis Syariah di Tengah Pandemi Covid-19}

Kegiatan para muslimah dalam komunitas Jogja Muslimah Preneur dapat mewujudkan bentuk peran muslimah dalam mengembangkan bisnis yang sesuai dengan ajaran syariah tanpa melupakan kodratnya sebagai perempuan. Keterlibatan gerakan dakwah komunitas memperlihatkan posisi startegis perempuan dalam pembangunan.Keterlibatan dan partisipasi perempuan secara aktif di sektor publik dan organisasi sosial memberikan warna baru terhadap proses rekonstruksi sosial masyarakat muslim. Kegiatan dan event yang diadakan komunitas JMP memberikan timbal balik yang positif bagi anggotanya.

Kelas-kelas yang diadakan JMP sangat membantu permasalahan para pebisnis dan menyebarkan ilmu baru kepada anggotanya. Edukasi entrepreneurship melalui kelas-kelas tersebut dapat meningkatkan minat berwirausaha dan kemudian bisa mempengaruhi pengembangan digitalisasi usaha (Hadromi, 2017; Islami, 2019). Namun, selama pandemi Covid- 19 ruang gerak komunitas menjadi terbatas, hal ini menjadikan semua kegiatan beralih menjadi sistem online. Sedangkan mayoritas anggota komunitas JMP adalah ibu rumah tangga yang harus menjalanka perannya sebagai seorang ibu dan istri dirumah sehingga proses kegiatan kelas bisnis tidak bisa berjalan secara maksimal (Hasanah, 2013). Permasalahan masal dalam berbisnis yang dirasakan para anggota komunitas adalah penurunan omzet sejak adanya pandemi Covid-19.

Semua upaya yang dilakukan anggota seperti peralihan usaha ke masker, menekan biaya produksi dan marketing, fokus ke salah satu produk yang digemari masyarakat. Membuatbanyak promo seperti memberikan diskon, tidak menyediakan sistem ready namun beralih dengan sistem PO (Pre-Order), reshoot membuat foto katalog baru untuk produk lama agar menggiring perspektif konsumen merupakan 
upaya yang tepat karena peningkatan kualitas produk dan kualitas layanan memiliki peran positif dan signifikan dalam membangun kepuasan dan loyalitas konsumen (Tripayana \& Pramono, 2020).

Disamping permasalahan tersebut, ada beberapa usaha yang tidak mengalami penurunan seperti usaha Logo desain dan Bisnis milik ibu Fitria kusuma dan usaha cv.bima aksara nusa milik ibu Sholiha Wardawatiyang bergerak di bidang pengadaan barang laboraturium, bahan kimia, alat kesehatan. Karena hal tersebut menjadi komoditas yang banyak permintaannya di tengah pandemi.

Selain itu promosi yang dibuat dalam bentuk pamflet oleh komite komunitas juga memberikan kemudahan dalam melakukan kegiatan jual-beli baik dari segi penjual maupun pembeli. Anggota komunitas sebagai pelaku bisnis dapat meningkatkan kualitas layanan dan menambah jenis layanan seperti delivery order dan pembelian secara online dengan layanan aplikasi yang digunakan oleh konsumen seperti gojek,grab dan aplikasi lainnya(Hardilawati, 2020). Materi "Smartphone videography" dan "optimasi tiktok for bisnis" dimanfaatkan oleh para pebisnis sebagai salah satu upaya dalam meng-upgrade usahanya kepada kalangan pengguna sosial media. Menggunakan sosial media pada usaha yang dilakukan memberikan manfaat diantaranya sebagai galeri produk, mendata kebutuhan suplier, mendata kebutuhan distributor, survey target konsumen, dan memantau konsumen. Sosial media juga berfungsi sebagai forum diskusi, membantu pengambilan keputusan, media pemasaran dan iklan, mendata kebutuhan konsumen, memberikan respon pada konsumen, dan saran kontak personal dengan konsumen (Purwidiantoro et al., 2016).

Banyaknya usaha yang dilakukan komunitas JMP untuk mengenalkan komunitas JMP ke khalayak luas dan menggandeng Disperindag untuk memberikan ruang kepada anggota JMP dalam mempromosikan usahanya melalui pameranpameran merupakan upaya yang tepat. Pemberian diskon kepada anggota JMP yang berbelanja di tempat merchant yang bekerja sama dengan JMP memberikan keuntungan antara peserta UMKM dengan konsumen,pemasok dan relasi lainnya, semakin baik pula kemampuan peningkatan pemasarannya (Farida et al., 2017).

Bisnis syariah menjadi garis besar dalam penelitian ini sehingga usahausaha komunitas dalam mempertahankan syariat Islam dalam berbisnis juga perlu diperhatikan. Sampai saat ini ajaran muamalah disampaikan melalui kajian rutin yang diadakan oleh divisi Islamic Studies. Namun, menurut narasumber selama masa pandemi Covid-19 kajian yang diadakan oleh divisi Islamic Studies sedikit menurun, 
sehingga kelas bisnis syariah diajarkan oleh pihak luar komite yang ditanggungjawabi oleh $\mathrm{Bu}$ Wini Devina selaku mantan president JMP dan pengurus divisi Islamic Studies. Kelas bisnis yang diadakan bersifat umum untuk kalangan di luar komunitas JMP. Masyarakat membutuhkan pengetahuan tentang etika bisnis Islam meskipun usaha yang dijalankan masih dalam skala kecil.

Dari sebelas narasumber yang diwawancarai didapatkan hasil: mayoritas anggota komunitas JMP sudah mengetahui bagaimana berbisnis sesuai syariat Islam. Banyak anggota yang sekadar mengetahui secara garis besarnya, namun kurang mengerti secara detail ilmu-ilmu didalamnya. Mereka menjalankan bisnisnya sehari--hari dengan menerapkan etika bisnis yang diperbolehkan dalam islam. Pemahaman tersebut diperoleh dari jawaban pertanyaan yang diajukan peneliti kepada narasumber.

Hal tersebut bisa dilihat dalam kejujuran dan kejelasan terkait wujud barang yang dijual, mereka menjual produk yang jelas kehalalannya, menetapkan harga setara dengan harga pasaran, tetap menjaga kodratnya sebagai perempuan dalam berbisnis. Salah satu strategi yang mereka gunakan saat pandemi adalah menggunakan diskon atau potongan harga. Di Indonesia diskon diatur dalam Fatwa Dewan Syariah Nasional No: 16/DSN-MUI/IX/2000. Untuk melihat implementasi konsep bisnis syariah yang dipraktikan oleh anggota komunits JMP dapat diukur melalui indikator prinsip dan strategi bisnis serta manajemen bisnis syariah yang dipraktikkan (Antoni, 2016). (Antoni, 2016).(Lombok, 2016) Indikator tersebut dapat diuraikan sebagai berikut :

a. Produk yang menjadi komoditi utama usaha anggota komunitas JMP. Anggota komunitas JMP terdiri dari usaha pakaian, hijab, makanan, aksesoris rumah, bahkan jasa. semua barang yang diperjual-belikan merupakan yang jelas kehalalannya. Dari sisi maqasid, berjualan pakaian yang menutup aurat, makanan yang bersumber dari bahan yang halal dan jasa yang mempermudah kehidupan manusia adalah hal yang memiliki manfaat bagi kehidupan manusia terlebih di zaman yang modern ini.(Lombok, 2016)

b. Aspek manajemen keuangan, sumber permodalan diperoleh dari dana pribadi. Keikutsertaan gerakan sosial and charity yang diadakan komunitas JMP, seperti gerakan sedekah jum'at, penggalangan dana, menjadi donatur dalam orangtua asuh dapat menjadi salah satu indikator bahwa keungan dalam bisnisnya diperuntukkan untuk kepentingan amal jariyah sebagai bentuk kewajiban seorang muslim yang taat mengeluarkan sadaqah. 
c. Aspek pemasaran, dari hasil wawancara peneliti memperoleh data mengenai strategi marketing yang digunakan dalam mempertahankan bisnisnya selama pandemi Covid-19. Mengadakan diskon, promo spesial, menentukan harga yang kompetitif dengan harga pasar sehingga tidak memonopoli harga. Menggunakan aplikasi tik-tok dan instagram dalam pemasaran produknya dengan tetap memperhatikan etika bisnis yang seharusnya.

d. Aspek sumber daya manusia, pengembangan SDM yang beretos Islami dapat dilihat dari pengamatan sosial media beberapa pengusaha dari anggota komunitas JMP. Seperti karyawan Ibu Iffah pemilik Batik Sogan dan Ibu Dian pemilik disera agency. Dari aktivitas yang diperlihatkan dalam media sosial khususnya instagram, setiap karywan memiliki hubungan yang harmonis dengan karyawan yang lainnya. Tetap memperhatikan batasan-batasan perempuan dan laki-laki dalam bekerja.

Indikator-indikator tersebut dapat dijadikan salah satu cara dalam menentukan tolak ukur seorang pengusaha dalam kesesuaian menjalankan bisnisnya dengan syariat yang diharuskan. Jumlah narasumber yang diambil belum bisa menjadi kesimpulan secara garis besar. Namun dari data narasumber yang diambil, menjelaskan bahwa komunitas JMP telah memenuhi perannya sebagai komunitas yang dapat menaungi anggotanya dengan baik dan mempertanggung jawabkan komunitasnya yang membawa kata "muslimah", sehingga kata muslimah dalam nama komunitasnya tidak hanya sekadar berarti perkumpulan wanita tetapi komunitas perempuan yang melakukan pergerakan dibidang bisnis dengan tidak melupakan kodratnya sebagai seorang perempuan dan tetep menjalankan bisnis sesuai syariat Islam.

\section{SIMPULAN}

Peran Komunitas dalam Mengembangkan Bisnis Syariah di Tengah Pandemi Covid-19 adalah komunitas membangun koneksi bisnis dan membangun komunitas Jogja Muslimah Preneur (JMP) melalui membuatkan kelas-kelas bisnis yang sangat berguna untuk para anggota komunitas JMP. Komunitas juga memfasilitasi dengan serangkaian kegiatan-kegiatan Social and Charity (SC), Event Organizer (EO), Public Relation (PR), dan Islamic Studies (IS). Selain itu, Komunitas JMP juga membangunkan koneksi bisnis antara para anggotanya dengan partner JMP untuk keberhasilan usaha-usaha yang dijalankan oleh anggota JMP selama masa Pandemi Covid-19 atau bahkan seterusnya. Dalam mewujudkan misinya, komunitas berusaha menjaga 
hubungan tali persaudaraan antar anggota dan terus memupuk jiwa entrepreneur kepada setiap anggota komunitas. Namun fokus komunitas terhadap kegiatan pengembangan bisnis syariah masih kurang.

Berdasarkan penelitian yang dilakukan, strategi yang dilakukan komunitas untuk mempertahankan nilai-nilai syariah dalam bermuamalah melalui kegiatan kegiatan yang diadakan oleh komite komunitas JMP. Nilai-nilai syariah dimasukkan dalam setiap materi kelas bisnis dan selalu rutin mengadakan kajian. Anggota komunitas JMP mempraktikan nilai-nilai syariah melalui bisnis yang dilakukan setiap harinya dengan memperhatikan indikator-indikator yang ditetapkan. Berdasarkan data diatas, kita dapat menarik kesimpulan: anggota komunitas JMP telah mengetahui dan menjalankan usahanya sesuai dengan syariah yang diajarkan meskipun tidak semua anggota memahami secara mendalam bagaimana praktik bisnis syariah yang sesungguhnya.

Untuk perbaikan kedepan, komunitas JMP mengkhususkan setiap kelas yang diadakan agar sesuai bidangnya, seperti kelas dengan materi bisnis kuliner untuk anggota yang sedang atau akan menjalani bisnis kuliner dan begitu juga dengan dengan bidang lainnya, sehingga ilmu yang didapatkan oleh anggota lebih maksimal. Mendatangkan narasumber yang benar-benar ahli dalam tema yang diangkat. Lebih memfokuskan pada peningkatan kualitas komunitas dengan membangun relasi yang banyak dan memperbanyak kelas-kelas bisnis. Adanya harapan dari pengurus komite komunitas JMP kepada anggotanya untuk lebih aktif dalam kegiatan yang diadakan dan aktif melakukan promosi dalam grub, maka menjadi saran untuk anggota komunitas agar lebih terbuka dan aktif berkomunikasi dengan angota senior lainnya. 


\section{DAFTAR PUSTAKA}

Agustin, H. (2017). Studi Kelayakan Bisnis Syariah. Rajawali Pers.

Ali, M. D. (2011). Hukum Islam, Pengantar Ilmu Hukum dan Tata Hukum Islam di Indonesia. PT RajaGrafindo Persada.

Amri, A. (2020). Dampak Covid-19 Terhadap UMKM di Indonesia [The Impact of Covid-19 on MSMEs in Indonesia]. Jurnal Brand, 2(1), 147-153. https://www. academia.edu/42672824/Dampak_Covid-19_Terhadap_UMKM_di_Indonesia

Antoni. (2016). Praktik Bisnis Syari'ah Usaha Dagang (UD) Toncell Mataram NTB [Business Practices Syari'ah Trading Business (UD) Toncell Mataram NTB]. Jurnal El-Hikam, 9(2), 423-449.

Ariyadi. (2018). Bisnis Dalam Islam [Business in Islam]. Jurnal Hadratul Madaniyah, 5(1), 13-26. https://doi.org/10.33084/jhm.v5i1.158

Aziza, A. (2018). Peran Entrepreneur Muslim dalam Membangun Koneksi dan Komunitas bisnis (Studi fenomenologi pada Pelaku Usaha Sari Bumi di Sidoarjo). Universitas Islam Negeri Sunan Ampel.

Basrowi. (2011). Kewirausahaan. Ghalia Indonesia.

Chilyatunnisa'. (2016). Pengembangan Bisnis Melalui Model Waralaba Syari'ah di Laundry Polaris Semarang. Universitas Islam Negeri Walisongo.

Ciputra. (2009). Solusi Job Creation di Tengah Krisis Global. SK Indopos.

Daryanto. (2018). Pengantar Ilmu Kewirausahaan (p. 60). Tira Smart.

Erviani, A. (2017). Peran Komunitas UINPreneurs dalam Memotivasi Mahasiswa untuk Melakukan Wirausaha di UIN Syarif Hidayatullah Jakarta. In skripsi (Vol. 110, Issue 9). Universitas Islam Negeri Syarif HIdayatullah.

Farida, N., Naryoso, A., \& Yuniawan, A. (2017). Model Pemasaran Hubungan dan E-Commerce dalam Meningkatkan Kinerja Pemasaran UKM Batik [Model of Relationship Marketing and E-Commerce in Improving Marketing Performance of Batik SMEs]. Jurnal Dinamika Manajemen, 8(36), 20-29.

Hadromi. (2017). The pattern of performance management of community service learning empowerment in improving the entrepreneurship on the graduation candidate of Vocational Technology Education Institution. AIP Conference Proceedings, 1818. https://doi.org/10.1063/1.4976878 
Hardilawati, W. laura. (2020). Strategi Bertahan UMKM di Tengah Pandemi Covid-19 [MSME Survival Strategies Amid the Covid-19 Pandemic]. Jurnal Akuntansi Dan Ekonomika, 10(1), 89-98. https://doi.org/10.37859/jae.v10i1.1934

Hasanah, H. (2013). Peran Strategis Aktivis Perempuan Nurul Jannah Al Firdaus Dalam Membentuk Kesadaran Beragama Perempuan Miskin Kota [The Strategic Role of Female Activist Nurul Jannah Al Firdaus in Forming the Religious Awareness of Poor Urban Women]. Inferensi, 7(2), 473. https://doi.org/10.18326/infsl3. v7i2.473-492

Hastuti, P. dkk. (2020). Kewirausahaan dan UMKM. Yayasan Kita Menulis.

Islami, N. N. (2019). The effect of digital literacy toward enterpreneur behaviors through students' intention enterpreneurship on Economics Education Study Program at Jember. IOP Conference Series: Earth and Environmental Science, 243(1). https://doi.org/10.1088/1755-1315/243/1/012084

Masruri, N. T. (2014). Pandangan Hukum Islam terhadap Pelaksanaan Khiyar dan Garansi pada Produk Elektronik (Studi Kasus di Service Center Lenovo, Semarang). Universitas Islam Negeri Walisongo.

Maulina, F., \& Listyani, R. H. (2020). Peran Perempuan Anggota Komunitas Pahlawan Ekonomi Dalam Meningkatkan Perekonomian Keluarga (Studi Pada Perempuan Dengan Suami Tidak Bekerja Dan Single Parent) [The Role of Women Members of the Community of Economic Heroes in Improving the Family Economy]. Jurnal Paradigma, 8(2), 1-19.

Meutia, I. F., Yulianti, D., Djausal, G. P., \& Sujadmiko, B. (2021). Fostering entrepreneurial ecosystem within rural enterpreneurship. International Journal of Entrepreneurship, 25(3), 1-10. https://www.scopus.com/inward/ record.uri?eid=2-s2.0-85104111221\&partner $I D=40 \& \mathrm{md} 5=5 f 581 \mathrm{~b} 62 \mathrm{~b} 1 \mathrm{aeb} 8$ eed80a2b3651adce6e

Neuman,W. L. (2013). Metode Penelitian Sosial: Pendekatan Kualitatif dan Kuantitatif. In edisi ke tujuh. INDEKS.

Nurhayati. (2018). Memahami Konsep Syariah, Fikih, Hukum dan Ushul Fikih [Understand the concepts of Sharia, Jurisprudence, Law and Usul Fiqh]. Jurnal Hukum Ekonomi Syariah, 2(2).

OECD. (2020). Covid-19: SME Policy Responses. Oecd 2020, March, 1-55. https:// oecd.dam-broadcast.com/pm_7379_119_119680-di6h3qgi4x.pdf

Pakpahan, A. K. (2020). Covid-19 Dan Implikasi Bagi Usaha Mikro, Kecil, Dan Menengah [Covid-19 and its implications for micro, small and medium 
enterprises]. Jurnal Ilmiah Hubungan Internasional, 59-64. https://doi. org/10.26593/jihi.v0i0.3870.59-64

Purwidiantoro, M. H., Kristanto, D. F., \& Hadi, W. (2016). Pengaruh Penggunaan Media Sosial Terhadap Usaha Kecil Menengah (UKM) [The Effect of Social Media Use on Small and Medium Enterprises (SMEs)]. AMIK Cipta Darma Surakarta, 1(1), 30-39.

Putra, M. U. M. (2015). Strategi Peningkatan UMKM terhadap Pembangunan Ekonomi Kota Medan (Studi Kasus: UMKM Komunitas Kelembagaan Tangan di Atas (Tda) Kota Medan) [Strategies for Increasing UMKM Against Economic Development in Medan City (Case Study: UMKM Community Institutiona. Jurnal Wira Ekonomi Mikroskil: JWEM, 5(02), 91-99. https://www.mikroskil. ac.id/ejurnal/index.php/jwem/article/view/230

Rahmanto, B. T., Nurjanah, S., \& Darmo, I. S. (2018). Peran Komunitas Dalam Meningkatkan Kinerja Ukm (Ditinjau Dari Faktor Internal) [The Role of Community in Improving Sme Performance (Viewed From Internal Factors)]. Jurnal Riset Manajemen Dan Bisnis (JRMB) Fakultas Ekonomi UNIAT, 3(1), 1-10. https://doi.org/10.36226/jrmb.v3i1.80

Undang-Undang Republik Indonesia Nomor 17 Tahun 2013, (2013).

Satuan Tugas Penanganan Covid-19. (2020). Peta Sebaran COVID-19. https:// covid19.go.id/peta-sebaran-covid19

Sugiarto, E. (2015). Menyusun Proposal Penelitian Kualitatif Skripsi dan tesis (p. 09). Suaka Media.

Takhim, M. (2016). Sistem Ekonomi Islam dan Kesejahteraan Masyarakat [Islamic Economic System and Community Welfare]. Jurnal Studi Islam Dan Sosial, 10(2), 4.

Tripayana, S., \& Pramono, J. (2020). Kualitas Produk, Pelayanan, dan Loyalitas Pelanggan Dimana Kepuasan Sebagai Variabel Intervening pada UKM Start Up Pariwisata Kombuchi Brewing Co, Bali [Product Quality, Service, And Customer Loyalty Where Satisfaction Is An Intervening Variable In The Ko. Jemap, 2(2), 182. https://doi.org/https://www.researchgate.net/deref/ http\%3A\%2F\%2Fdx.doi.org\%2F10.24167\%2Fjemap.v2i2.2266

Usniah, S., \& Alhifni, A. (2017). Karakteristik Entrepreneur Syariah Pada Usaha Mikro, Kecil dan Menengah (UMKM) di Bogor [Characteristics of Sharia Entrepreneurs in Micro, Small and Medium Enterprises (MSMEs) in Bogor]. Jurnal Syarikah, Volume 3(1). 